\title{
NORMAL AND EXPERIMENTAL VARIATIONS IN ACID EXCRETION BY THE LAYING HEN
}

\author{
R.-S. ANDERSON (1) \\ Unilever Research Laboratory, \\ Colworth House, Sharnbrook, Bedford (Great-Britain)
}

\section{INTRODUCTION}

In the fowl, as in other animals, the maintenance of acid-base equilibrium within normal limits is dependent on chemical and physiological compensatory mechanisms. Unlike other animals, however, the laying fowl must compensate for the regular daily occurrence of an acute metabolic acidosis. This acidosis coincides with the period of shell calcification (Mongin and LACASSAGNE, 1964) and, apart from the immediate contribution of the blood buffers to the maintenance of homeostasis, there is evidence of both respiratory and renal compensation (MONGIN and LACASSAGNE, I965; ANDERSON, I967; TAYLOR and KIRKLEY, I967).

If acid-base balance is further altered by experimental means, the amount of calcium carbonate which is deposited on the shell membrane may be increased or decreased (Hunt and AitKen, I962; HELbaCKA, CASTERLINE and SMith, I963; FRANK and BuRGER, I965; HowES, I966). HuNT and AITKEN (I962) suggested that, since total plasma calcium level was not altered in the laying bird during ammonium chloride acidosis, the reduction in shell thickness which was observed was due to a limitation in the formation of carbonate radicals rather than to the reduced availability of calcium for shell formation. A marked increase in urinary calcium excretion during ammonium chloride acidosis nevertheless occurs in man (MARTIN and JoNES, I96I), thus an effect of ammonium chloride on calcium metabolism in the fowl cannot be discounted.

There is, therefore, substantial evidence that shell calcification and acid-base status of the fowl are interrelated (see MonGIN, I968). Much, however, remains to be learned of this relationship and how it may be exploited to provide optimum dietary and environmental conditions for the production of eggs of adequate shell thickness and strength.

(1) Present address : Nutritional Research Laboratory, Petfoods Limited, Melton Mowbray, Leicestershire (Great-Britain). 
This paper deals with some of the changes in acid-base excretion associated with egg formation in the intact and colostomized fowl under normal conditions and during ammonium chloride acidosis. Some of the observations have previously been reported in brief form (ANDERSON, I967).

\section{METHODS}

Light hybrid hens (Thornber 606 and Shaver 288) were used. Pre-lay birds were I9-20 weeks of age and laying birds were $24-31$ weeks of age. They were kept in individual cages at a controlled temperature $\left(\mathrm{I} 6-20^{\circ} \mathrm{C}\right)$ with $\mathrm{I} 2$ hour artificial light per day and received a complete layers ration (No. I Complete Specialist Layers Chips or Mash-B. O. C. M.) and water ad lib. The ammonium chloride ration was prepared by mixing 2 p. Too of ammonium chloride with the control ration.

Some birds were colostomized using a stainless steel cannula (HILI and ANDERSON, unpublished) and others using a modification of the technique described by Fussell (I960). Urine was collected in a light polythene bag held in place over the vent by a light harness. Droppings and urine $\mathrm{pH}$ measurements were made with a direct reading $\mathrm{pH}$ meter (Model $23 \mathrm{~A}, \mathrm{E}$. I. L.) and a spear glass electrode, and urinary total $\mathrm{CO}_{2}$ was measured with a microgasometer (NATELSON, I95 I). Urine bicarbonate concentration was calculated by substitution of the measured $\mathrm{pH}$ and total $\mathrm{CO}_{2}$ values in the Henderson-Hasselbach equation using a value of 6 .I for $\mathrm{pK}^{\prime}$ and 0.0309 as the solubility factor. Urinary sodium and calcium estimations were made by atomic absorption flame spectrophotometry (SP.9o, Unicam).

Capillary blood samples were obtained by clipping a claw after immersion of the foot in warm water $\left(5^{\circ} \mathrm{C}\right)$ for 2 minutes. Blood $\mathrm{pH}$ measurements were carried out on the Astrup Microequipment (Type AME I, Radiometer). Bicarbonate concentration and $\mathrm{pCO}_{2}$ was derived from the published nomogram (SIGAARD-ANDERSEN, I962).

Shell thickness was calculated from the Specific Gravity of the whole egg (TYLER and GEAKE, I96I), using a hydrometer to obtain the weight of the egg in water (WELLS, I967).

\section{RESULTS}

\section{Acid-base changes in the excreta on a standard diet}

Normal hens.

Droppings $p H$. - Measurement of droppings $\mathrm{pH}$ at intervals before and after oviposition was carried out on 17 birds. The mean post-oviposition $\mathrm{pH}$ was higher than the mean pre-oviposition $\mathrm{pH}$ in 45 out of 49 observations. (mean $\mathrm{pH}$ difference $=0.69 \pm 0.38 \mathrm{~S}$. D.). In 23 of the observations, no egg was laid on the following day, but the increase in the droppings $\mathrm{pH}$ of this group after oviposition was not significantly different from that of the group in which an egg was laid on the following day.

In a more detailed study, droppings were collected at hourly intervals throughout each I 2 hour light period for 4 days from 3 laying and 3 non-laying birds. The droppings evacuated during 12 hours of darkness were also collected and the $\mathrm{pH}$ measured, after it had been established that the change in the $\mathrm{pH}$ of droppings kept at room temperature over I2 hours was negligible. The $\mathrm{pH}$ changes and their relationship to oviposition are shown in figure. I. The mean value from the 3 non-laying birds $(8.02 \pm 0.25$ S. D.) was significantly higher $(p<0.001)$ than that from the 3 laying birds $(6.5 \mathrm{I} \pm 0.78 \mathrm{~S}$. D.). Throughout the experimental period, the hourly variation in the droppings $\mathrm{pH}$ of the non-laying birds was less than that of the laying birds. 
There was no consistent over-all pattern in the dropping $\mathrm{pH}$ values of the 3 laying birds, although bird 5/1896 showed changes apparently related to oviposition - the laying of each egg being preceded by a period when the droppings $\mathrm{pH}$ was low and being followed by a marked rise in $\mathrm{pH}$ at oviposition. Low $\mathrm{pH}$ values (approximately 6.0) were recorded for approximately to hours before the first egg was laid, the main decrease having occured during the $\mathbf{I} 2$ hours of darkness immediately preceding the beginning of this period. After the post-oviposition rise in $\mathrm{pH}$, values decreased gradually to about 6.0 some 20 hours before laying of the second egg.
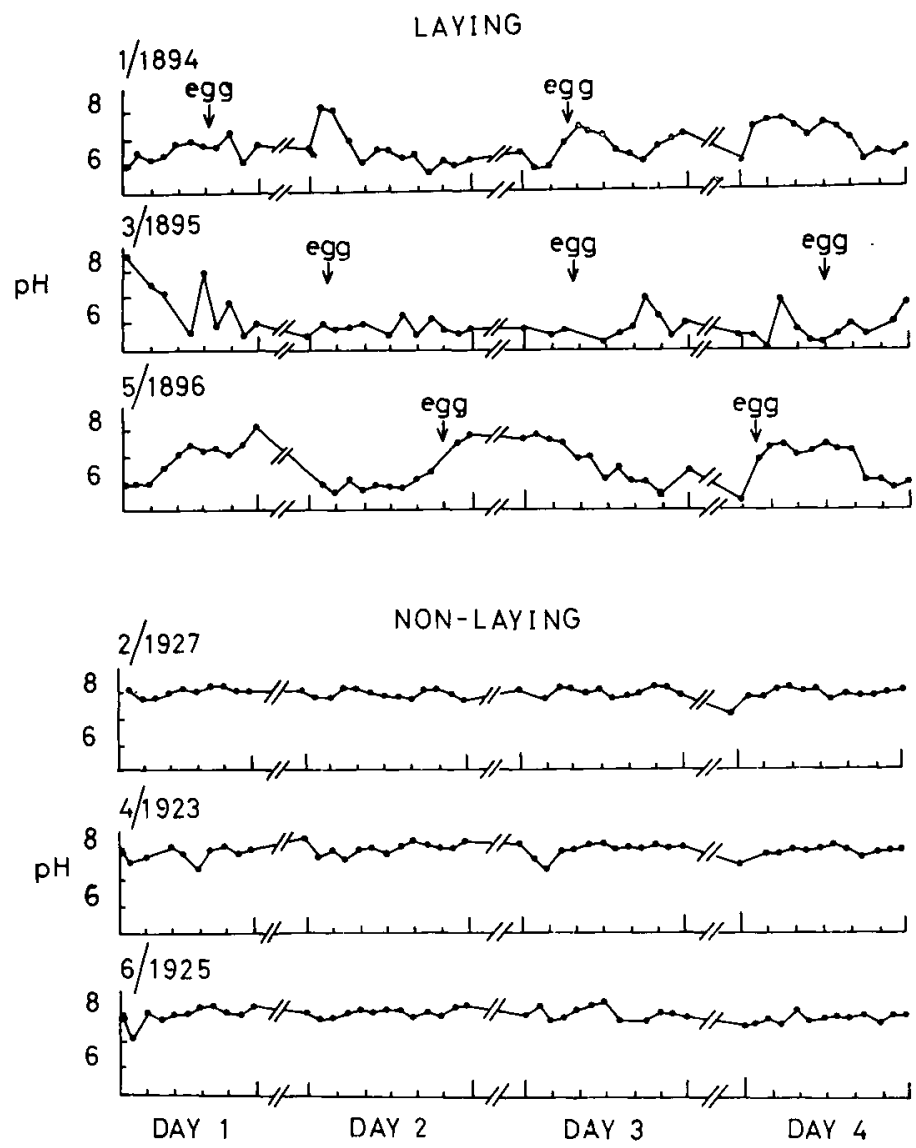

FIG. I. - The $p H$ values of droppings collected at hourly intervals from 3 laying and 3 non-laying hens. The first value on each day, except day $I$, is from droppings excreted during the preceding $\mathrm{I} z$ hour period of darkness. The subsequent values are from droppings excreted during the i 2 hour period of light.

\section{Colostomized hens.}

Urine $p H$ and bicarbonate concentration. - In order to ascertain whether the urinary or the alimentary component of the droppings was primarily responsible for the $\mathrm{pH}$ changes observed, experiments were carried out on colostomized birds. Urine $\mathrm{pH}$ and bicarbonate measurements were made at consecutive 2 hour intervals on laying colostomized birds for periods up to 3 days. Urine $\mathrm{pH}$ decreased from values around 
8.020 hours before oviposition to about 5.5 I 4 hours before oviposition (fig. 2). 'These low values were maintained until oviposition, when within 2 hours, there was a rapid increase to $\mathrm{pH}$ 8.o. Urine bicarbonate concentration was high (20-40 meq /1),

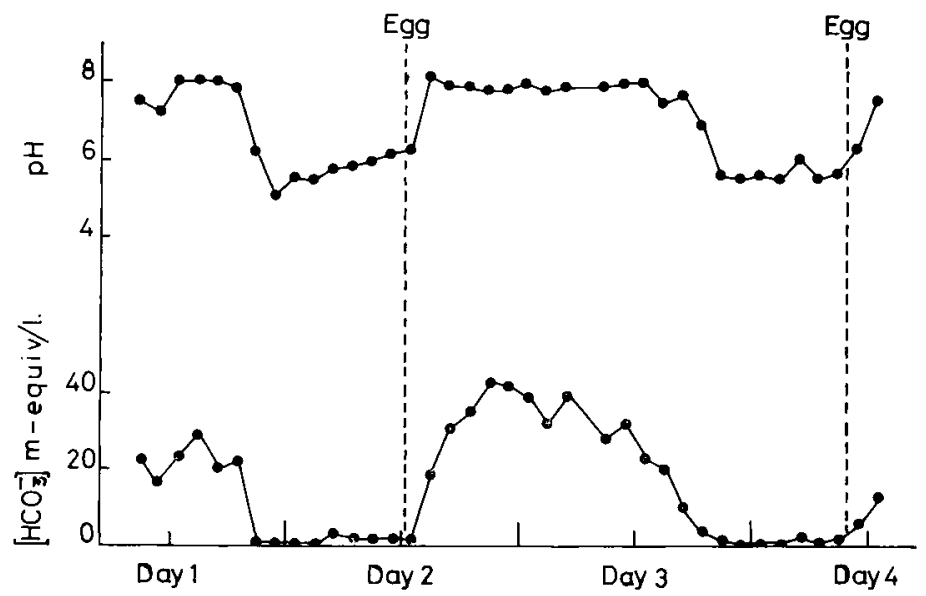

FIG. 2. - The pH and bicarbonate values of urine samples collected from a colostomized hen at 2 hour intervals over a period of four days

until 20 or more hours before oviposition but little or no bicarbonate was present during the last $\mathrm{I}_{4}$ hours of shell formation. The $\mathrm{pH}$ of the fæces collected from the stoma remained consistently high (about 8.o) during all these observations. Similar $\mathrm{pH}$ changes were observed during the formation and oviposition of 8 eggs (fig. 3).

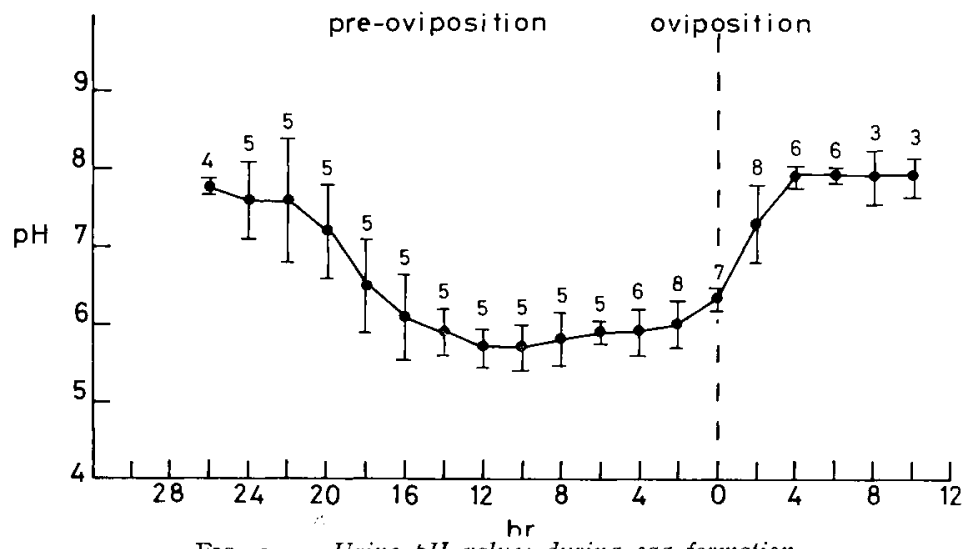

FIG. 3. - Urine $p H$ values during egg formation

Mean and standard deviation of values obtained from experiments on four colostomized hens.

The number of individual observations is shown above each point on the graph

\section{Acid-base changes during ammonium chloride acidosis}

Normal hens.

Six out of twelve 26 week old Shaver 288 hens (Group A). were given the control ration throughout the three periods of the experiment. The remaining six birds 
(Group B) received the control ration for Io days (Period I), the 2 p. Ioo ammonium chloride ration for $2 \mathrm{I}$ days (Period 2) and the control ration for a further $2 \mathrm{I}$ days (Period 3) (table I).

\section{TABLE I}

Design of the experiment to establish the effect of ammonium chloride acidosis on normal laying hens (Shaver 288).

\begin{tabular}{|c|c|c|c|}
\hline & $\begin{array}{c}\text { Period } 1 \\
\text { (10 days) }\end{array}$ & $\begin{array}{l}\text { Period } 2 \\
\text { (21 days) }\end{array}$ & $\begin{array}{c}\text { Period } 3 \\
\text { (21 days) }\end{array}$ \\
\hline $\begin{array}{l}\text { Group A }\left(^{1}\right) \\
\text { (control) }\end{array}$ & $\begin{array}{l}\text { Control } \\
\text { diet }\end{array}$ & $\begin{array}{l}\text { Control } \\
\text { diet }\end{array}$ & $\begin{array}{l}\text { Control } \\
\text { diet }\end{array}$ \\
\hline $\begin{array}{l}\text { Group } B(1) \\
\text { (test) }\end{array}$ & $\begin{array}{l}\text { Control } \\
\text { diet }\end{array}$ & $\begin{array}{c}\text { Test diet } \\
\left(2 \% \mathrm{NH}_{4} \mathrm{Cl}\right)\end{array}$ & $\begin{array}{l}\text { Control } \\
\text { diet }\end{array}$ \\
\hline
\end{tabular}

(1) 6 hens in each group.

Droppings $p H$. - The mean $\mathrm{pH}$ of the droppings was significantly decreased during the feeding of ammonium chloride (table 2 ). The droppings $\mathrm{pH}$ of both groups increased inexplicably during Period 3 when all birds received the control ration.

TABLE 2

The $p H$ of droppings of during control and test periods. The values given represent the mean $p H$ of all droppings evacuated during each period

\begin{tabular}{|c|c|c|c|}
\hline & Period 1 & Period : & Period 3 \\
\hline $\begin{array}{l}\text { Group A } \\
\text { (control) }\end{array}$ & $5.7_{t}^{\prime}$ & 5.86 & 6.56 \\
\hline $\begin{array}{l}\text { Group B } \\
\left(\mathrm{NH}_{4} \mathrm{Cl} \text { in }\right. \\
\text { Period }-2)\end{array}$ & 5.82 & $5.57\left(^{*}\right)$ & 6.55 \\
\hline
\end{tabular}

(*) Significant difference from Group A $(p<0.05)$.

Shell thickness, blood $p H$ and other parameters. - Eggs from the test group (Group B) showed a significant decrease in shell thickness during Period 2, but egg production and weight were not affected (table 3 ).

There was a significant decrease in the $\mathrm{pH}$ and bicarbonate concentration (but not the $\mathrm{pCO}_{2}$ ) of the capillary blood during ammonium chloride acidosis (table 4).

The food intake of both groups increased throughout the three periods of the 
experiment and was not affected by the inclusion of ammonium chloride in the ration. Water intake, however, showed a highly significant increase when the test ration was fed, returning to its previous level on resumption of the control ration (table 5) Droppings moisture and the volume of water excreted in the droppings also showed a large increase in association with the feeding of the ammonium chloride ration.

TABLE 3

Shell thickness $(\mu)$ derived from Specific Gravity measurements. Mean values from all eggs collected during each period

\begin{tabular}{c|c|c|c}
\hline \hline & Period 1 & Period 2 & Period 3 \\
\hline $\begin{array}{c}\text { Group A } \\
\text { (control) }\end{array}$ & 330 & 331 & 3147 \\
\hline $\begin{array}{c}\text { Group B } \\
(\mathrm{NH} \text { Cl in } \\
\text { Period 2) }\end{array}$ & 330 & $308\left(^{*}\right)$ & 335 \\
\hline
\end{tabular}

$\left(^{*}\right)$ Significant difference from Group A $(p<0.05)$.

\section{Colostomized hens.}

Two colostomized laying hens were fed the 2 p. Ioo ammonium chloride ration for three days following a control period of six days. The pattern of urinary changes was similar in both birds, thus the findings from one bird only are reported.

Urine and faces output. - There was a marked diuresis when the ammonium chloride diet was fed; urine flow increased from an average rate of $2.4 \mathrm{ml} / \mathrm{h}$ during the control period to $4.8 \mathrm{ml} / \mathrm{h}$ during ammonium chloride acidosis. (fig. 4). There was little variation in the total daily output of fæces nor in the fæcal moisture content during the experiment.

Calcium excretion. - An egg was laid on each day of the experiment except Day 5. (fig. 5). On the preceding day (Day 4) - the only day on which egg formation did not occur - there was a marked calciuria. There was no increase in urinary calcium excretion on days 7,8 and 9 when the ammonium chloride ration was fed, though there was a marked diuresis. As in the previous experiment with intact birds, there was a reduction in shell thickness during this period.

The fæcal excretion of calcium showed a two-fold increase on Day 4 (the non-eggforming day) but, unlike the urinary pattern, excretion remained relatively high on days 6,7 and 8 , returning on Day 9 to approximately the same level as on the first three days of the control diet. The total output of fæces remained fairly constant throughout the experiment.

The total (fæcal and urinary) calcium excretion during ammonium chloride administration was not substantially different from that of the control period. 


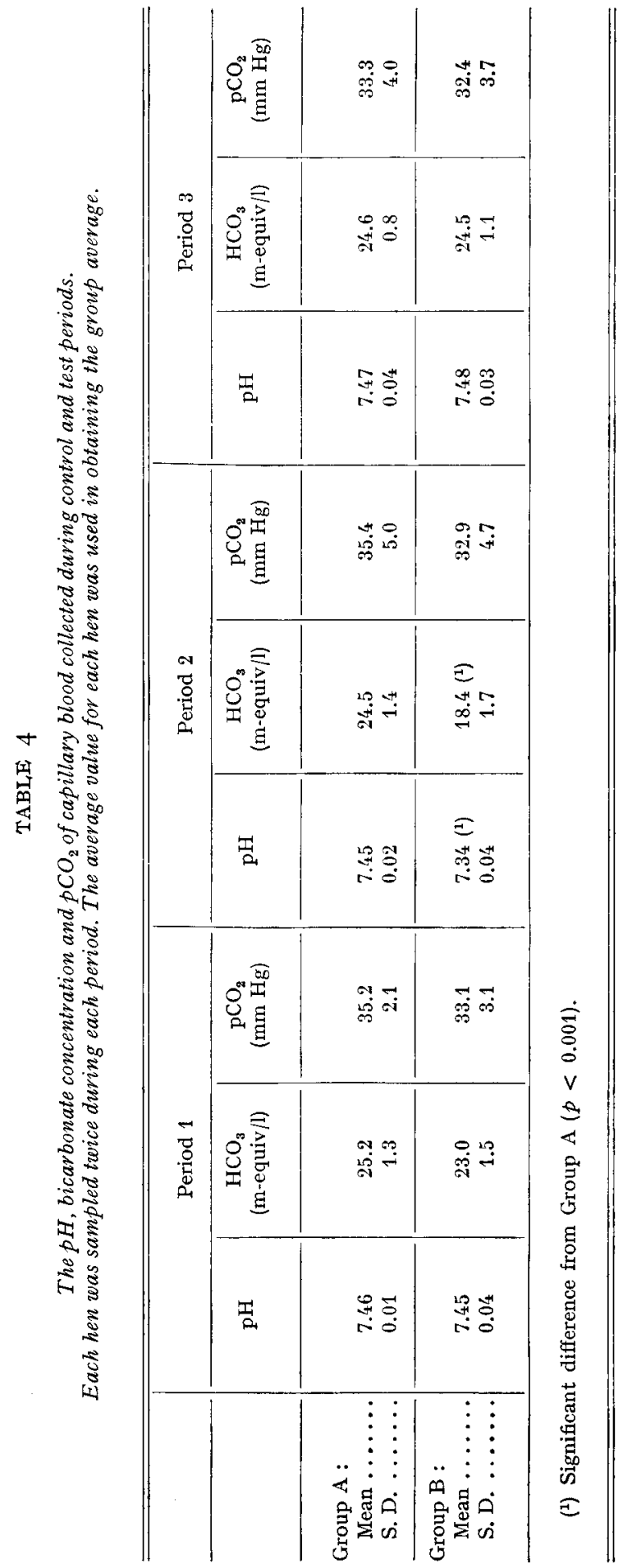


R.-S. ANDERSON

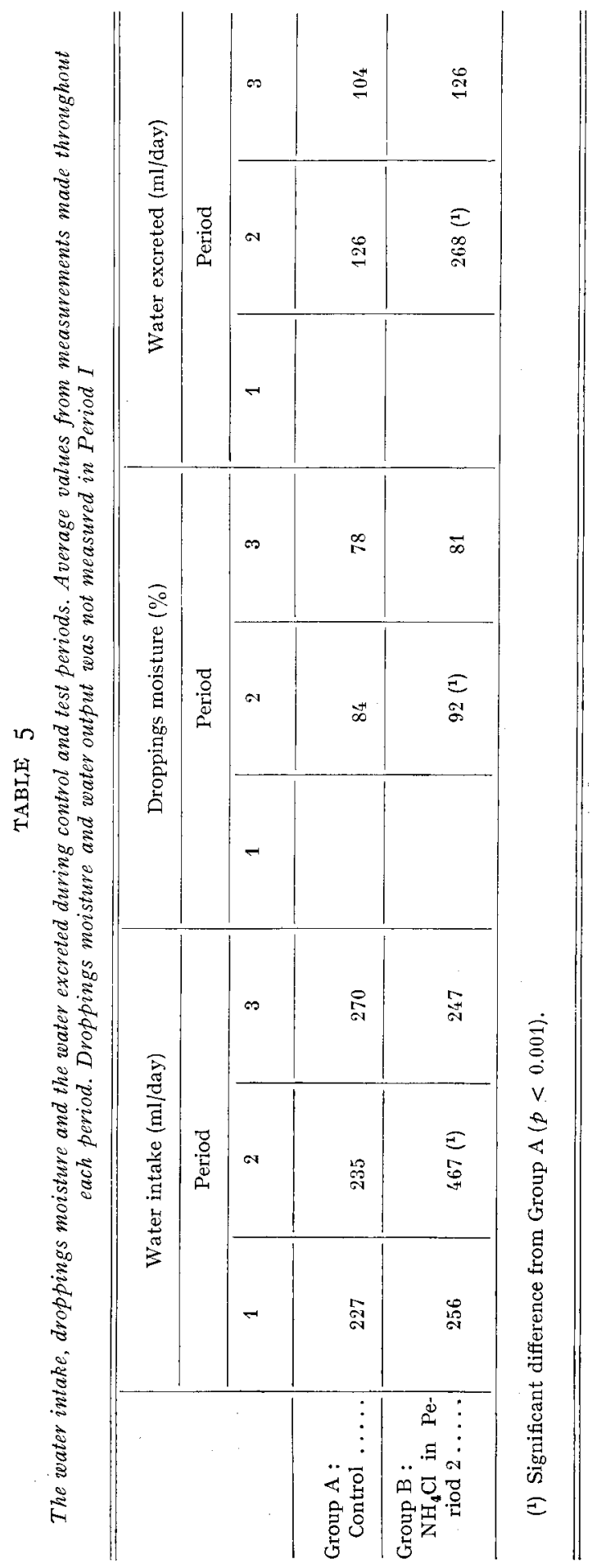




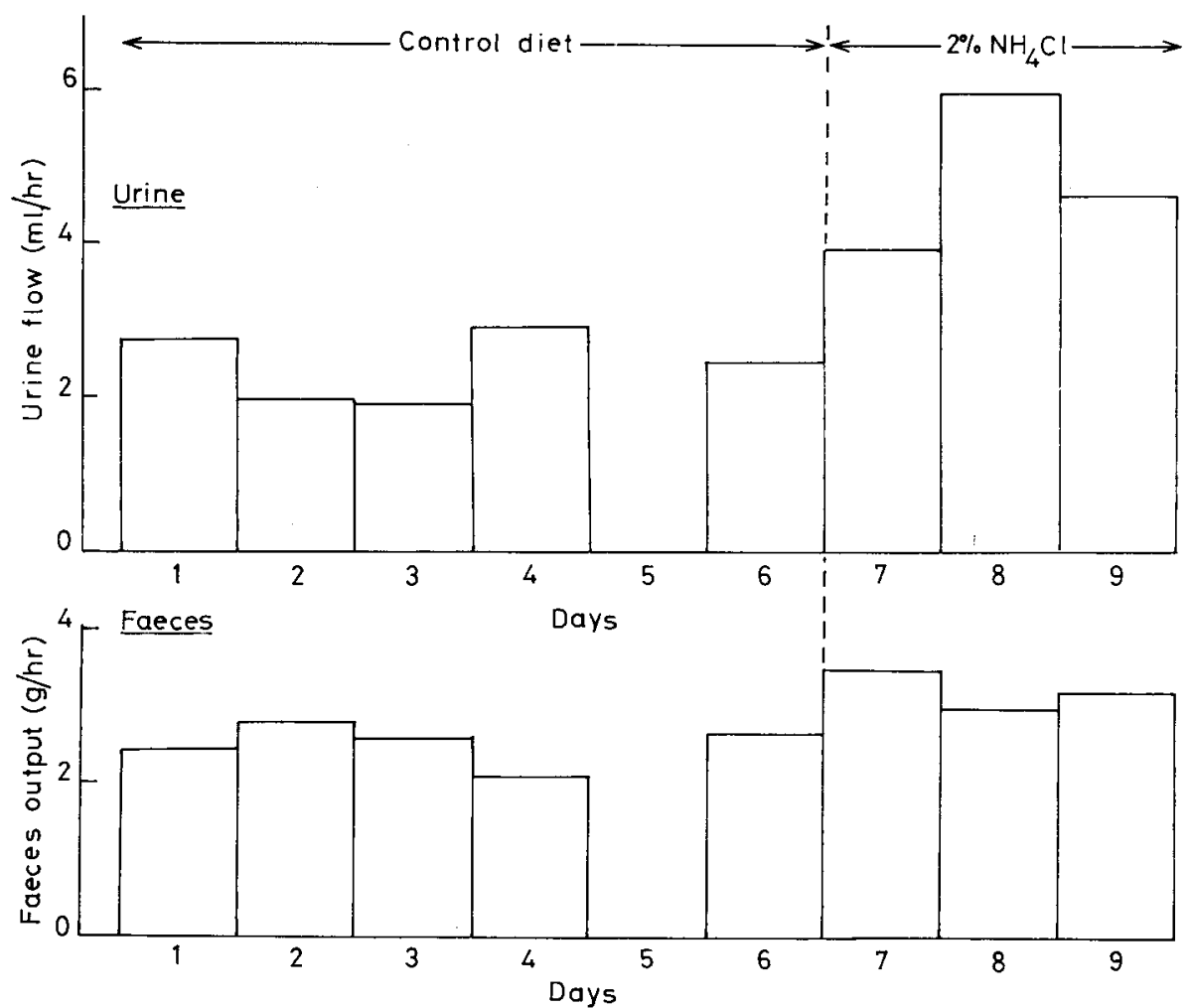

FIG. 4. - The average rate of urine and faces output by a colostomized laying hen receiving the control diet (days $\mathrm{I}-6$ ) and a diet containing 2 p. 100 ammonium chloride (days 7-9).

Collection was incomplete on day 5

\section{CALCIUM OUTPUT}

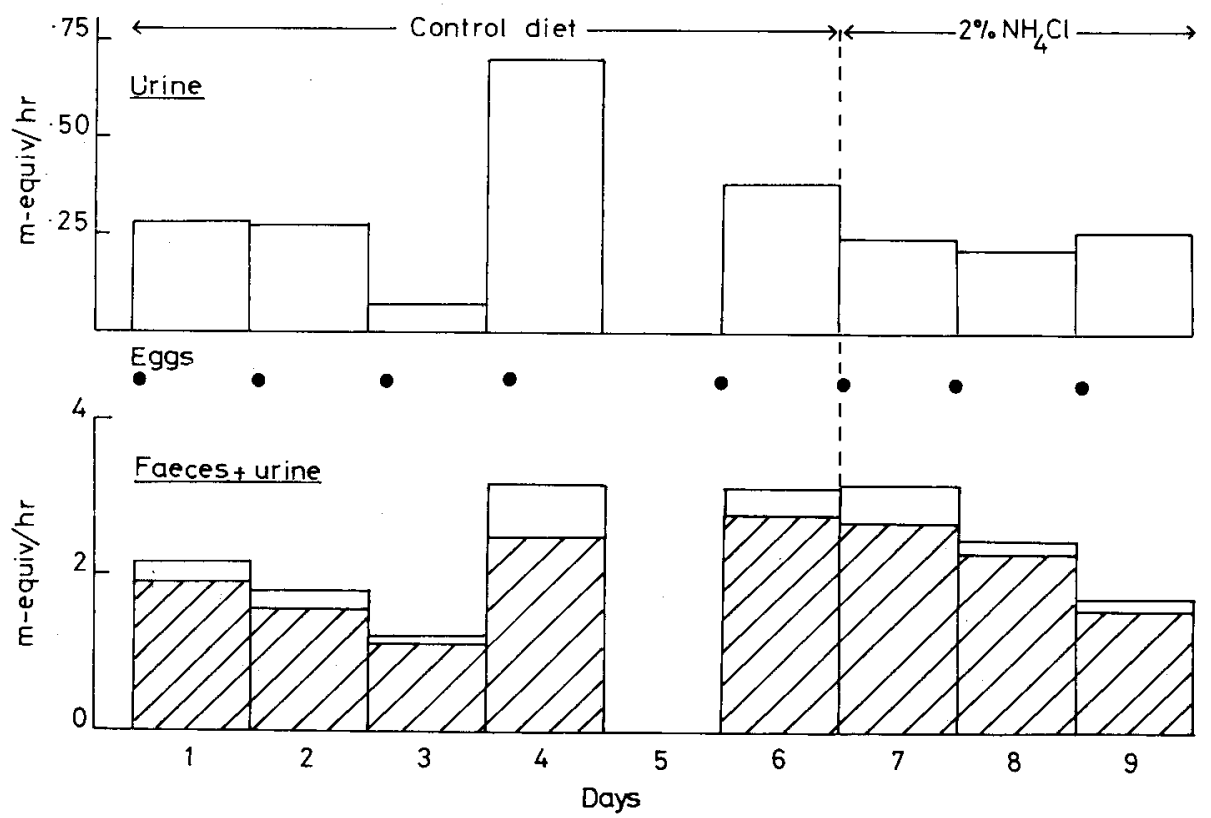

FIG. 5. - The average rate of urinary and fecal calcium output by a colostomized laying hen receiving the control diet followed by the $2 \mathrm{p}$. 100 ammonium chloride diet

Collection was incomplete on day 5 . The hatched areas represent fæcal output 
Sodium excretion. - Urinary sodium output remained fairly constant during the control period, but a very marked natriuresis occurred when the ammonium chloride ration was fed (fig. 6) reaching a maximum rate on Day 8.

\section{SODIUM OUTPUT}

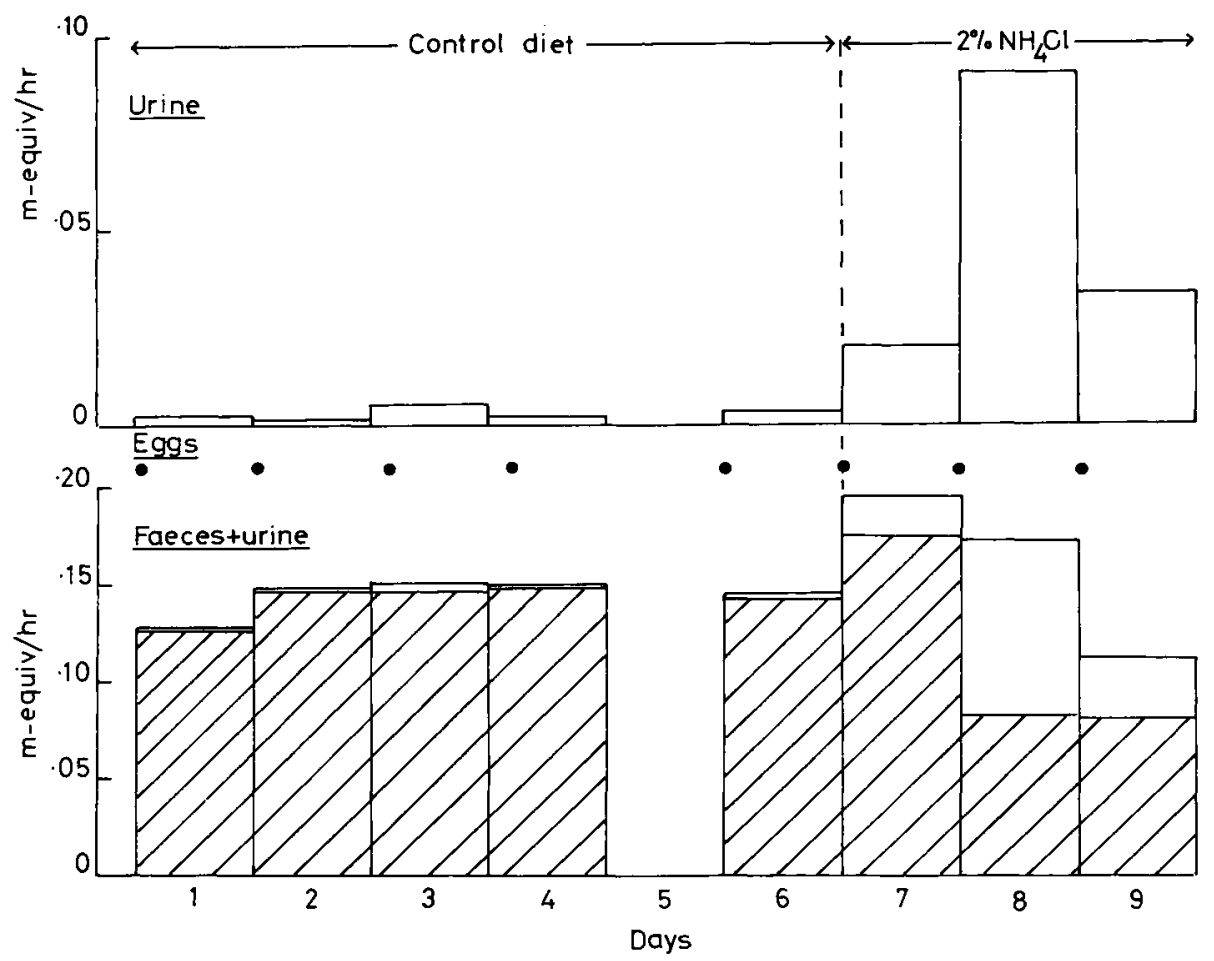

FIG. 6. - The average rate of urinary and facal sodium output by a colostomised laying hen receiving the control diet followed by the $2 p .100$ ammonium chloride diet.

Collection was incomplete on day 5 . The hatched areas represent fæcal output

There was little daily variation in freal sodium excretion during the control period and although a slight increase occurred on the first day of ammonium chloride administration, on Days 8 and 9 excretion decreased to a level below that of the control period.

The total (fæcal and urinary) sodium excretion increased on Days 7 and 8 , but returned to the control level on Day 9.

Urine $p H$. - Measurements of urine $\mathrm{pH}$ were not made at regular intervals but the values during the control period showed a similar relationship to egg formation to that seen in the previous experiment (fig. 7). On Days 7,8 and 9 , however, there was a downward trend in urinary $\mathrm{pH}$ values, reaching a lower limit of $\mathrm{pH}$ 5.I. 'The marked increase which occurred immediately after oviposition on Days $I-6$ was almost abolished when the ammonium chloride diet was fed. 


\section{URINE}

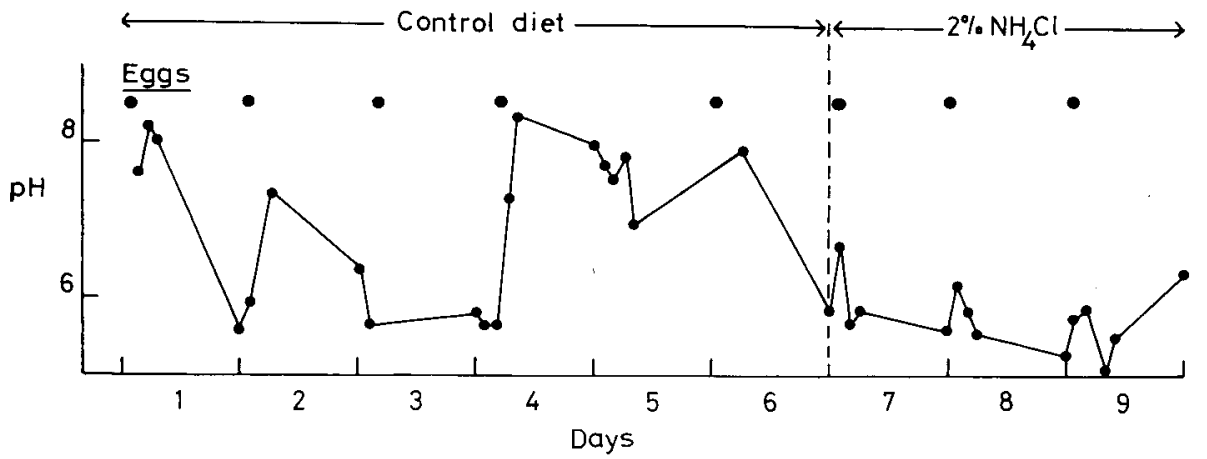

FIG. 7. - Urinary $p H$ values from a colostomized laying hen receiving the control diet followed by a $2 p .100$ ammonium chloride diet.

\section{DISCUSSION AND CONCLUSIONS}

Since both laying and non-laying birds received the same ration in Experiment $\mathbf{I}$, the relatively greater acidity of the droppings from the laying birds may be assumed to be of metabolic rather than dietary origin. The clear relationship between the increased excretion of acid and the period of shell calcification which was seen in the urine of colostomized birds was not, however, so apparent in the excreta of the intact birds. The more irregular fluctuations in droppings $\mathrm{pH}$ are probably explained by the varying proportions of fæces and urine in the mixture of which the droppings are comprised. If, as seems probable from studies on colostomized birds, fæcal material does not pass into the colon at a constant rate, then the droppings $\mathrm{pH}$ will vary according to the extent by which the urine is diluted and buffered by the fæces. Furthermore, there is now convincing evidence that post-renal urinary re-absorption occurs in the large bowel (SkADHAUGE, I967) and the extent to which such re-absorption has occurred will further modify the final $\mathrm{pH}$ of the droppings. Whether or not post-renal urinary re-absorption plays a significant role in the maintenance of acidbase equilibrium is, however, open to question, since the acid-base status of the colostomized laying fowl does not appear to differ from that of the intact bird (ANDERSON, unpublished).

The decrease in urinary bicarbonate and $\mathrm{pH}$ during the $\mathrm{I} 8$ hours preceding oviposition corroborates the observation that shell calcification is associated with a metabolic acidosis (MONGIN and LACASSAGNE, r964), and the titratable acidity of the urine and hence its efficiency in eliminating acid is greatly enhanced by the phosphaturia which coincides with the period of shell calcification (FUSSELL, I960). Renal excretion of acid thus contributes substantially to the maintenance of acid-base equilibrium in the laying hen, thus any impairment of renal function may readily affect shell calcification through failure to compensate for the associated acidosis.

The failure to demonstrate convincingly any marked increase in calcium excre- 
tion in association with ammonium chloride acidosis appears to corroborate the contention of HUNT and AITKEN (I962) that the decrease in shell thickness under these conditions is not due to an effect on calcium metabolism. If, however, calcium absorption, excretion and total blood calcium remain unaltered, the decreased output of calcium in the egg shell must, presumably, be balanced by decreased mobilization of calcium from the tissues.

The natriuresis and diuresis which occurred during ammonium chloride acidosis is well recognized in other species (SMITH, I95I), but has not, apparently, been reported previously in the fowl. It may be that much of the urinary sodium excreted by the colostomized fowl during acidosis would have been re-absorbed in the intact fowl, but the very low rate of urinary sodium excretion found during the control period suggests that the margin of safety for the manipulation of potentially acidforming raw materials in rations of low sodium content is rather narrow.

\section{SUMMARY}

The $\mathrm{pH}$ of droppings from normal laying and non-laying hens and the faccal and urinary $\mathrm{pH}$ and urinary bicarbonate concentration from colostomized laying hens were measured at regular intervals. The $\mathrm{pH}$ of droppings from the non-laying hens was significantly higher than that from the laying hens, in which there was some evidence of a decrease in the $\mathrm{pH}$ of droppings excreted during shell calcification. Urine $\mathrm{pH}$ and bicarbonate concentration invariably decreased during shell calcification and increased after oviposition.

During acidosis induced by dietary ammonium chloride, there was a decrease in the pH of the droppings and in the $\mathrm{pH}$ and bicarbonate concentration of the capillary blood of normal hens. Urinary calcium excretion of colostomized hens did not increase, but there was a marked increase in urinary sodium excretion. The observations support the contention that the decrease in shell thickness associated with ammonium chloride acidosis is not due primarily to an effect on calcium metabolism.

\section{RÉSUMÉ,}

\section{VARIATIONS NORMALES ET EXPÉRIMENTALES DE L'EXCRÉTION D'ACIDES CHEZ LA POULE PONDEUSE,}

Le $\mathrm{pH}$ des déjections de poules normales pondeuses et non pondeuses ainsi que le $\mathrm{pH}$ des fèces et de l'urine et la concentration des bicarbonates urinaires de poules pondeuses à anus artificiel ont été mesurés à intervalles réguliers. Le pH des déjections des poules non pondeuses est significativement plus élevé que celui des poules pondeuses, pour lesquelles nous avons remarqué une nette diminution du $\mathrm{pH}$ des déjections lors de la formation de la coquille. Le $\mathrm{pH}$ et la teneur en bicarbonates de l'urine diminuent invariablement pendant la calcification de la coquille et augmentent après la ponte de l'œuf.

Au cours d'une acidose produite par l'ingestion de chlorure d'ammonium, il apparait chez les poules normales une diminution du pH des déjections ainsi que du pH et de la teneur en bicarbonates du sang capillaire. L'excrétion de calcium dans l'urine des poules à anus artificiel n'est pas augmentée mais il y a un accroissement sensible de l'excrétion urinaire de sodium. Ces observations permettent de prétendre que la diminution d'épaisseur de la coquille liée à l'acidose induite par le chlorure d'ammonium n'est pas due en premier lieu à un effet sur le métabolisme calcique. 


\section{REFERENCES}

Anderson R.S., 1967. Acid-base changes in the excreta of the laying hen. Vet. Rec. 80, $314-315$.

Frank F. R., BURger R. E., I965. The effect of carbon dioxide inhalation and sodium bicarbonate ingestion on egg shell deposition. Poult. Sci., 44, I604-I606.

Fussert M. H., 1960. Studies on calcium and phosphorus metabolism in the hen. $\mathrm{Ph} \mathrm{D}$. Thesis, University of Cambridge.

Helbacka N. V., Casterline J. L., Smith C. J., 1963. The effect of high $\mathrm{CO}_{2}$ atmospheres on the laying hen. Poult. Sci., 42, 1082-1084.

Howes J. R., I966. Egg shell quality as affected by the addition of bicarbonate to the feed and water (abstract). Poult Sci. 45, I092-1093.

Hunt J R., Aitken J. R., 1962. The effect of ammonium and chloride ions in the diet of hens on egg shell quality. Poult. Sci., 41, 434-438.

Martin H. E., Jones R., I96I. The effect of $\mathrm{NH}_{4} \mathrm{Cl}$ and $\mathrm{NaHCO}_{3}$ on the urinary excretion of magne. sium, calcium and phosphate. Am. Heart. J. 62, 205-2 10.

Mongin P., I968. Role of acid-base balance in the physiology of egg shell formation. Worlds Poult. Sci. J, 24, 200-230.

Mongin P., Lacassagne L., r964. Physiologie de la formation de la coquille de l'œuf de Poule et équilibre acido-basique du sang. C. R. hebd. Séanc. Acad. Sci. Paris, 258, 3093-3094.

Mongin P., Lacassagne L., 1964. Physiologie de la formation de la coquille de l'œuf de Poule et ventilation pulmonaire. C. $r$. hebd. Séanc. Acad. Sci. Paris, 261, 4228-4229.

Natelson S., r95I. Routine use of ultramicromethods in the clinical laboratory. Am. J. clin. Path. 21, II 53-II72.

SigaARd-Andersex 0. I 962 . The $\mathrm{pH}-\log \mathrm{pCO}_{2}$ blood acid-base nomogram revised. Scand. J. clin. Lab. Invest. 14, 598-604.

SkADhaUge E., I967. In vivo perfusion studies of the cloacal water and electrolyte resorption in the fowl (Gallus domesticus). Comp. Biochem. Physiol., 23, 483-50r.

Sмiтн H. W., 195I. The Kidney. Oxford University Press : New York.

TAYLOR T. G., KIRKLEY J., r967. The absorption and excretion of minerals by laying hens in relation to egg shell formation. Br. Poult. Sci., 8, 289-295.

Trler C., Geake F. H., I961. Studies on egg shells. XV. Critical appraisal of various methods of assessing shell thickness. J. Sci. Fd. Agric. 12, 28 I-289.

Wells R. G., 1967. Egg shell strength. I. The relationship between egg breakage in the field and certain laboratory assessments of shell strength. Br. Poult. Sci., 8, I3I-I 40. 